\title{
SPECIAL INTERROGATORIES TO JURIES IN CIVIL CASES
}

\author{
WILLIAM H. WICKER
}

With the increasing complexity of affairs in our modern commercial and industrial society, the need for increasing the security of transactions and acquisitions becomes more acute. One sign that this need is being felt is the growing dissatisfaction with the manner in which the jury is exercising the extravagant powers granted to it during an age when the economic interests were relatively simple and the jury was looked upon more as a bulwark against tyranny and corruption than as an efficient instrument of justice according to law. There can be little doubt that the fact that the plaintiff happens to be indigent or that the defendant is personally unpopular or is a corporation, often has far greater effect upon the jury than the abstract charge of the trial judge. The writer purposes in the present paper to discuss the development of the law relating to the submission of special interrogatories to juries, in order to ascertain to what extent this method is effective in confining the jury to its legitimate function as trier of disputed facts.

For centuries the great check on the jury was the attaint. ${ }^{1}$ If the verdict was wrong the jury was subject to attaint, whether the error was in finding the facts or in determining their legal consequences. As it was palpably unfair to subject the jurors to the severe punishment of attaint for a bona fide error of law, they were given the privilege of returning a special verdict in civil cases, at an early period in common law history. ${ }^{2}$ There can be little doubt that the jury's fear of the attaint was far more potent in developing the special verdict than any feeling that they were incompetent to understand the law or to apply it to the facts. After the harsh and cumbersome attaint had become unworkable, the judges tried other means of mitigating the injustice resulting from verdicts which were clearly contrary to the law and the weight of the evidence. The most important of these was the growing practice of granting new trials. ${ }^{3}$ The judges also not infrequently, either lawfully or unlawfully, ordered the jury to return a special verdict, and enforced their orders by threats, by

\footnotetext{
1.Thayer, Preliminary Treatise on Evidence (1898) 140.

2 Scott, Fundamentals of Procedure (1922) 95; Morgan, A Brief History of Special Verdicts and Special Interrogatories (1923) 32 YaLe LAW JourNAI, 588; Panel v. Moor (1553) 1 Plow. 91; Dowman's Case (1586) 9 Coke, $* 7 \mathrm{~b}$.

31 Holdsworth, $A$ History of English Law (3d ed. 1922) 225, 226.
} 
punishment or by granting a new trial.' The practice also grew up of quizzing the jury not only when they had returned a special verdict, but also occasionally when they had returned a general verdict. 5 The English juries from time to time resisted these attempts to compel them to account for their verdicts; and in the end this resistance has apparently resulted in the complete acceptance of their view by the English courts. Under the present English practice, it is the privilege of the jury to deeline to find any other than a general verdict, even though the judge requests them to give a special verdict; ; and in the absence of consent of the parties and of the jury it is not proper for the trial judge to direct the jury to return answers to special questions with their general verdictz. After a general verdict has been returned, the trial judge is not entitled to ask any further questions of the jury for the purpose of ascertaining the grounds for the verdiet. ${ }^{5}$

The general tendency in this country has been to increase the power of the jury beyond all English precedents ${ }^{3}$; but in respect to special verdicts and special interrogatories we have actually decreased the power of the jury to a considerable extent. The old custom of the English judges of quizzing a jury who had returned an unexpected verdict was apparently adopted early in the judicial history of Massachusetts. In Pierce $v$. Wooduca $d^{80}$ it is stated that "where the judge is surprised by the verdict, it is not unusual to ask the jury upon what principle it was found". Some of the other New England states, relying on the MIassachusetts precedents, soon adopted the same practice."1 This practice was of such practical utility that it was early extended so as to allow special questions to be submitted to the jury, answers to which were to be returned with the general verdict.12

In New York the practice of submitting to the jury speeial interrogatories to which answers were to be returned with the general verdict was sanctioned by the Supreme Court of that

1 Thayer, op. cit. supra note 1 , at 217,218 .

5 Miorgan, op cit. supra note 2, at 591; 2 Pollock and Maitland, History of English Law (2d ed. 1898) 631.

- IIayor and Burgesses of Devizes v. Clarls (1835, K. B.) 3 Ad. \& E. $50 \dot{6}$.

7 Walton v. Potter et al. (1841, C. P.) 3 Mian. and G. 411, 433 .

${ }^{s}$ Brown v. Bristol and Esetcr $R y$. (1861, Exch.) 4 L. T. (s. S.) 830; Arnold v. Jeffreys [1914] 1 K. B. 512.

${ }^{9}$ Thayer, loc. cit. supra note 1 ; Sunderland, The Ineficioney of the American Jury (1915) 13 IITCH. L. REv. 302.

10 (1828, MIass.) 6 Pick. 206, 208; see also Hix v. Drery (1827, Mass.) 5 Pick. 296; Parrott et al. v. Thacher et al. (1830, MIass.) 9 Picls. 425; Doir v. Fenno (1832, Míass.) 12 Pick. 521.

${ }^{11}$ Smith v. Putiney (1841) 18 Me. 87; Waller v. Savyer (1842) 13 N. H. 191; Smith v. Powers (1844) 15 N. H. 546.

12 Gordon v. Wilkins (1841) 20 Mfe. 134; Graves v. Washington Merine Insurance Co. (1866, MIass.) 12 Allen, 391; Cummings and Co. v. Aldrich (1854) 29 N. H. 63; Wheeler v. Schroeder (1850) 4 R. I. 383; Spaulding v. Robbins et al. (1869) 42 Vt. 90. 
state prior to the adoption of the Code of Procedure of $1848 . .^{13}$ That code contained two sections $\mathbf{s}^{14}$ authorizing a continuance of this practice. These two sections are in part as follows: "the court may direct the jury to find a special verdict in writing, upon all or any of the issues; or may instruct them, if they render a general verdict, to find upon particular questions of fact, to be stated in writing, and may direct a written finding thereon." "The special verdict or finding shall be filed with the clerk, and entered upon the minutes." "Where a special finding of facts shall be inconsistent with the general verdict, the former shall control the latter, and the court shall give judgment accordingly."

These sections, in common with most of the other provisions of that Code, have been copied, either directly or indirectly, in a more or less modified form, by a majority of the American state legislatures, and have been incorporated into their various codes of civil procedure. The statutes in force at the present time in twenty-nine of the American states and in the Territory of Alaskn contain express provisions relating to special findings by the jury in addition to the general verdict. In twenty-two of these states and in the Territory of Alaska ${ }^{15}$, the submission of interrogatories, answers to which are to be returned with the general verdict, is discretionary with the court by the language of the statute, notwithstanding a request by one or both of the parties. The phraseology of these statutes differs to some extent, but they are all substantially to the effect that the court "may" require the jury to find specially on one or more questions of fact in any case in which they return a general verdict. The language of the statutes of the remaining seven states, ${ }^{16}$ as to the court's duty when a party requests the submission of interrogatories, is mandatory. These statutes likewise differ in their phraseology, but

${ }_{13}$ McMasters et al. v. Westchester County Mut. Ins. Co. (1841, N. Y. Sup. Ct.) 25 Wend. 379.

It N. Y. Laws, 71 Sess., 1848, ch. 379, secs. 216, 217.

15 Alaska, Comp. Laws, 1913, sec. 1037; Arkansas, Crawford and Moses Digest, 1921, sec. 1303; Arizona, Civ. Code, 1913, par. 543; Californin, Deering C. C. P. 1923, sec. 625 ; Colorado, Comp. Laws, 1921, C. C. P. sec. 219; Idaho, Comp. Sts. 1919, sec. 6861; Kentucky, Carroll's Codes of Practice, 1919, sec. 327; Minnesota, Gen. Sts. 1913, sec. 7808; Montana, Rev. Codes, 1921, sec. 9361; Nebraska, Comp. Sts. 1922, sec. 8804; Nevada, Rev. Laws 1919, sec. 5222; New York C. P. A. 1921, sec. 459; North Carolina, Cons. Sts. 1919, sec. 587; North Dakota, Comp. Laws, 1013, sec. 7633; Oklahoma, Comp. Sts. Ann. 1921, sec. 552; Oregon, Laws, 1920, sec. 154; South Carolina, C. C. P. 1922, sec. 542; South Dakota, Rev. Code, 1919, sec. 2520; Utah, Comp. Laws, 1917, sec. 6821; Washington, Remington's Comp. Sts. 1922, sec. 364; West Virginia, Barne's Code Ann. 1923, ch. 131, sec. 5; Wisconsin, Sts. 1921, sec. 2858; Wyoming, Comp. Sts. 1920, sec. 5780 .

${ }^{16}$ Illinois, Smith-Hurd's Rev. Sts. 1923, ch. 110, sec. 79; Indiana, Burn's Ann. Sts. 1914, sec. 572; Iowa, Comp. Code, 1919, sec. 7523; Kansas, Rev. Sts. 1923, ch. 60, sec. 2918; Michigan, Comp. Laws, 1915, sec. 12611; Ohio, 
are substantially to the effect that, at the request of a party, the trial court "shall" ${ }^{17}$ direct the jury to find on particular questions of fact in addition to a general verdict.

Of the twenty-nine states in which the statutes make the submission of interrogatories discretionary with the trial court, it has been held in three, namely, California, Oregon and Washington, that in so far as a refusal to submit interrogatories is concerned, the discretion is absolute and cannot be reviewed on appeal. ${ }^{18}$ The submission of improper or misleading interrogatories is obviously a more serious matter than a refusal to submit proper interrogatories; and no state has gone so far as to hold that there is no review of a submission of improper interrogatories. The Supreme Court of Oregon has apparently gone as far as any court in the direction of making the decision of the trial court final. As to the latter question, that court in White 2 . White ${ }^{10}$ said, "The nature and form of the particular questions are largely within the discretion of the trial judge, and unless it is apparent that there was a clear abuse of such discretion, or unless the question submitted even upon immaterial or inconclusive matters was palpably misleading as to the main issue, or could not be answered without danger of confusion or misrepresentation, it would not afford ground for reversal."

According to the weight of authority and what the writer believes to be the better view, the discretion vested by this group of statutes in the trial court is a discretion subject to review either as to the submission, or as to the refusal to submit interrogatories; but the action of the trial court is reversible error only in case of a clear showing that it has abused its discretion by acting arbitrarily. ${ }^{20}$ In the seven states ${ }^{22}$ in which the statutes

\footnotetext{
Throckmorton, Gen. Code Ann. 1921, sec. 11463; Rhode Island, Gen. Laws, 1923 , sec. 4983.

$1 \pi$ The constraining word used in the statutes of Illinois and Iowa is "must" instead of "shall".

${ }^{18}$ Eaton v. Southem Pac. Co. (1913) 22 Calif. App. 461, 134 Pae. 801; Swift v. Mulkey (1886) 14 Or. 59, 12 Pac. 76; Fos v. Tift (1010) 57 Or. 268, 111 Pac. 51; Tallace o. American Life Ins. Co. (1924) 111 Or. 510, 225 Pac. 192; Pencil v. Home Ins. Co. (1892) 3 Wash. 485, 28 Pac. 1031; Aeres v. Frederick and Nelson, Inc. (1914) 79 Wash. 402, 140 Pac. 370.

19 (1899) 34 Or. 141, 159, 55 Pac. 645, 650.

20 Burlie v. McDonald (1890) 2 Idaho, 616, 33 Pac. 49; Fodey v. Nortlccri Pac. Ry. (1912) 21 Idaho, 713, 123 Pac. 835; Iltis v. Chicago M. and St. P. Ry. (1889) 40 Minn. 273, 41 N. W. 1040; Moody v. Canadian Northcra Ry. (1923) 156 Minn. 211, 194 N. W. 639; Chicago, St. Paul, M. and 0. Ry. v. Lagerkrans (1902) 65 Neb. 566, 91 N. W. 358; Mangum a. Bullion Becli and Champion Ifin. Co. (1897) $15 \mathrm{Utah}, 534,50$ Pae. 834; T. Dolmen Co. v. Niagra Fire Isz. Co. (1897) 96 Wis. 38,71 N. W. 69 . The statutes of West Virginia expressly provide that the action of the trial court on a motion to submit interrogatories shall be subject to review. Sce sugro note 15.

${ }^{21}$ Supra note 16.
} 
are mandatory in form providing that, at the request of a party the court "shall" or "must" submit interrogatories, a refusal by a trial court to submit them is not reversible error unless the questions were seasonably submitted, were proper in form and substance, and were not covered by others which were submitted. ${ }^{22}$ Under both groups of statutes the court may submit interrogatories to the jury of its own motion ${ }^{23}$ but need not do so. ${ }^{24}$ The state statutes relating to interrogatories are not within the meaning of the Federal Conformity Act, and hence are not applicable to the Federal courts. ${ }^{25}$ But at least two Federal courts relying on the New England precedents, ${ }^{26}$ independent of any statute, ${ }^{27}$ have sanctioned the practice of submitting interrogatories.

Statutes authorizing interrogatories have occasionally been attacked on the ground that they abridge the constitutional right of trial by jury. In Walker v. New Mexico, and S. P.R.R..$^{2 s}$ it was contended that an act of the legislature of the then Territory of New Mexico providing for special interrogatories violated the Seventh Amendment. In answering this contention the United States Supreme Court" said: "We are clearly of opinion that this territorial statute does not infringe any constitutional provision, and that it is within the power of the legislature of a territory to provide that on a trial of a common-law action the court may, in addition to the general verdict require specific answers to special interrogatories; and, when a conflict is found between the two, render such judgment as the answers to the questions compel." Obviously such statutes do not prevent the jury from passing on disputed questions of fact. They do provide a means of checking up the verdict and hence have a tendency to make the division of functions of court and jury more

${ }_{22}$ Chicago \& Alton R. R. v. Harrington (1901) 192 Ill. 9, 61 N. E. 622; Clegg v. Waterbury et al. (1882) 88 Ind. 21; Bower v. Bower (1895) 142 Ind. 194, 41 N. E. 523; Jones v. Annis (1891) 47 Kan. 478, 28 Pac. 156; Zucker v. Karpeles (1891) 88 Mich. 413, 50 N. W. 373; Cleveland C. C. and St. L. Ry. v. Village of St. Bermard (1899) 19 Ohio Cir. Ct. R. 296, 10 O. C. D. 415 .

${ }_{23}^{23}$ Lowman v. Sheets (1890) 124 Ind. 416, 24 N. E. 351; Miles v. Schrunti (1908) 139 Iowa, 563, 117 N. W. 971; Oliver v. Morawetz (1897) 97 Wis. 332,72 N. W. 877.

${ }^{24}$ Chicago \& Alton R. $R$. v. Elmore (1889) 32 Ill. App. 418.

25 Indianapolis and St. L. R. R. v. Horst (1876) 93 U. S. 291.

${ }^{26}$ Supra note 12. Rhode Island is the only New England state that has a statute on the subject, and in Rhode Island the practice of submitting interrogatories antedated the statute.

${ }_{27}$ Grand Trunk Western Ry. v. Lindsay (1912, C. C. A. 7th) 201 Fed. 836; Victor-American Fuel Co. v. Peccarich (1913, C. C. A. 8th) 209 Fed. 568; see also Walker v. New Mexico, and S. P. R. R. (1897) 165 U. S. 593, 17 Sup. Ct. 421.

${ }^{28}$ Supra note 27.

29 Supra note 27 , at 598, 17 Sup. Ct. at 423. 
effective by taking away from the jury some of its power to talie the law into its own hand. But, in so far as civil cases are concerned, this power is not ${ }^{30}$, and it is submitted, should not be, protected by constitutional safeguards.

The difference between a special verdict and special findings in response to interrogatories is clearly brought out in the following extract from an opinion of the Iowa Supreme Court, ${ }^{3}$. "There is . . . a manifest difference between a special verdict and the finding of the facts in answer to interrogatories propounded to the jury. A special verdict is in lieu of a general verdict, and its design is to exhibit all the ultimate facts, and leave the legal conclusions entirely to the court. . . . Sindings of fact in answer to interrogatories do not dispense with the general verdict. - . . A special verdict covers all the issues in the case, while an answer to a special interrogation may rell spond to but a single inquiry, pertaining merely to one issue, though essential to the general verdict." The great objection to the special verdict is the technical manner in which it must be formulated. Under our present system it must be "built up out of the facts shown in evidence, and that when so constructed it must on its face, taken in connection with the pleadings, constitute a technically sufficient foundation of fact for a judgment. Nothing else is to be looked to. All controverted facts not found therein are to be deemed non-existent. This means that either omissions of material facts, or employment of conclusions of law or matters of evidence instead of ultimate facts or the use of ambiguous and uncertain language will destroy the verdict as the foundation for a judgment." 32 These objections have very little force as applied to special findings accompanied by a general verdict, as judgment is entered on the general verdiet in all cases in which the special finding does not state facts requiring a different result.

Most of the general principles as to the form of interrogatories are elementary and are fairly stated by the Connecticut Supreme Court of Errors as follows, "They should be so clear and concise as to be readily understood and answered by the jury. Each question should call for a finding of but a single fact. When practical, each question should be so framed as to call for a

so Pittsburgh C. C. and St. L. Ry. v. Smith (1904) 207 Ill. 48G, 69 N. E. 873; Citizens St. R. R. v. Jolly (1903) 161 Ind. S0, 67 N. E. 935; Adams Adm'r. v. Louisville and N. R. R. (1885) $82 \mathrm{Ky}$. C03; Scott, op. cit. sujoro note 2 , at 96, 97, 106.

31 IIorbey v. Chicago N. W. Ry. (1902) 116 Iowa, 84, 89, 89 N. W. 105, 107. The court's citations of authorities are omitted.

32 Sunderland, Verdicts, General and Special (1920) 29 YALs LAW JounNaL, 253, 262. Professor Sunderland ably argues for a change in the method of drafting pleadings which will enable the pleadings themselves to be employed without change of form as the findings of the special verdict. 
categorical answer. Each question should ask for the finding of a fact and never for a conclusion of law. No question should ask for the finding of a purely evidential fact nor of an uncontroverted fact. Although not wholly covering, nor necessarily controlling, the determination of any issue framed, the fact sought to be elicited must be pertinent to some issue, and one which may be of material weight in deciding it. No interrogatory should be permitted, the response to which cannot serve either to limit or explain a general verdict or aid in the proceeding for a subsequent review of the verdict or judgment which may be rendered." "as It is held in a few jurisdictions that direct pertinent questions within the issues should be submitted, if requested, even though the most favorable answers to them would not control a general verdict in favor of the adverse party..$^{34}$ But the majority and better view is that only those questions should be submitted which, if answered most favorably to the party requesting them, would be inconsistent with a general verdict for his adversary. ${ }^{\text {at }}$ In some jurisdictions each question is tested separately so that, standing by itself, it must call for an answer which would control a general verdict for the adverse party..$^{38}$ Such a test seems to limit unduly the usefulness of interrogatories by making it difficult, if not impossible, for the party sustaining the affirmative of several issues to use them. Under such circumstances it is submitted that it would be much better to permit the use of several short questions which, when considered together, would call for answers controlling a general verdict for the adverse party, even though each question when considered alone would not have that effect.

It is improper for the trial court to instruct the jury that if the general verdict is for the party submitting interrogatories they need not be answered. ${ }^{37}$ In Rhode Island it has been held

${ }^{33}$ Freedman v. New York, N. H. and H. R. R. (1908) 81 Conn. 601, 614, 71 Atl. 901, 906.

${ }^{34}$ Brown Land Co. v. Lehman (1907) 134 Iowa, 712, 112 N. W. 185; Atchison, T. and S. F. R. R. v. Ayers (1895) 56 Kan. 176, 42 Pac. 722.

${ }^{35}$ Merrill v. Los Angeles Gas and Electric Co. (1910) 156 Calif. 499, 111 Pac. 534; Chicago Anderson Pressed-Brick Co. v. Reinneiger (1892) 140 III. 334, 29 N. E. 1106; First Nat. Bank of North Bend v. Miltonberger (1892) 33 Neb. 847, 51 N. W. 232.

${ }^{36}$ Fort Wayne Cooperage Co. v. Page (1908) 170 Ind. 585, 84 N. E. 145; Tyler v. Wright et al. (1915) 188 Mich. 561,155 N. W. 353.

${ }^{37}$ In Pitzer $v$. Indianapolis, $P$. and C. Ry. (1881) 80 Ind. 569, 572, Elliott, C. J. said: "There are strong reasons supporting the position that a court should not be allowed to submit interrogatories with instruction that if the general verdict is for the party submitting them, they need not be answered. In close cases it would induce weak jurors, and such thero sometimes are, to yield rather than undertake the labor of answering long and difficult interrogatories; it would induce ingenious counsel to frame many and perplexing interrogatories in the hope of driving the jurors to their side, in order to escape a laborious and irksome task." 
to be proper for the trial court to inform the jury of the legal effect of a certain answer to a question submitted to them for a special finding. ${ }^{38}$ But the majority rule, and the one which seems more consonant with the purpose of these statutes, is that an instruction informing the jury of the effect of a stated answer upon the ultimate result of the controversary should not be given.s In Coats v. Town of Stanton, ${ }^{30} \mathrm{MIr}$. Justice Pinney, of the Supreme Court of Wisconsin, in stating the reason for the latter view, said, "The jury had no right to be informed how any particular answer to a special question would affect the case, or what judgment would follow in consequence of it, for to impart such information would almost necessarily defeat the object intended to be secured by a special verdict. The object of the law is to secure fair and impartial answers to such questions, free from bias or prejudice in favor of either party or in favor of or against a particular result, and to guard against the danger of the result being affected or controlled by favor or sympathy, or by immaterial considerations." Following the same line of reasoning, but with less justification, some courts have held that it is reversible error to charge the jury that the special findings must conform to the general verdict."11 It is submitted that this view is too strict and is likely unduly to hamper the trial judge in his attempt to impress upon the jury the necessity of giving serious consideration to the answering of each question.

Where there is evidence bearing on a material interrogatory which is submitted, and the jury fails to answer it, or returns an answer consisting of "we don't know" or an evasive or an equivocal answer together with a general verdict, the court should require the jury to retire and return a direct answer.sz But if the court could have properly refused to submit the question in the first instance, it is not error for it to refuse to compel the jury to give a categorical answer..$^{43}$ An answer consisting of "we don't know" or a similar expression accepted by the court

3s Smith v. Rhode Island Co. (1916) 39 R. I. 146, 98 Atl. 1.

${ }^{39}$ Taylor v. Davarn (1916) 191 Mich. 243, 157 N. W. 572; Chrivtl e. Haveit (1917) 164 Wis. 624, 160 N. W. 1061.

40 (1895) 90 Wis. $130,136,62$ N. W. $619,621$.

$\$ 1$ Coffeyville Vitrified Brick Co. v. Zimmerman (1900) 61 Kan. 750, 60 Pac. 1064; Mechanies' Banli v. Barnes (1891) 86 Mtich. 632, 49 N. W. 475; contra: Capital City Banle v. Waliefield (1891) 83 Iowa, 40, 48 N. W. 1059. *2 Cleveland, C. C. and I. Ry. v. Asbury (1889) 120 Ind. 289, 22 N. E. 140; Atchison T. and S. F. R. R. v. Campbcll (1876) 16 Kan. 200; Steitard v. Henzingsen Produce Co. (1913) $88 \mathrm{Kan} .521,129$ Pac. 181; Rathbun Parker (1897) 113 Mich. 59.1,72 N. W. 31; Redford 2. Spolianc St. Ry. (1894) 9 Wash. 55, 36 Pac. 1085.

43 City of Indianapolis v. Keeley (1906) 167 Ind. 516, 79 N. T. 499 ; Cily of Wyandotte v. Gibson, Adm. (1881) $25 \mathrm{Kan}$. 236; Banncr Tobaceo Co. Jenison (1882) 48 Mich. 459, 12 N. W. 655; Netional Refining Co. :. Miller (1891) 1 S. D. 548,47 N. W. 962. 
without objection is equivalent to a finding against the party having the burden of proof.44

Of the thirty American jurisdictions ${ }^{45}$ which have statutes relating to special interrogatories, all except Arizona and Rhode Island expressly provide that, if a special finding of fact is inconsistent with a general verdict, the former controls and the court may give judgment accordingly. ${ }^{\star 6}$ But the courts have been rather reluctant to set aside general verdicts and enter judgment on special findings, and in interpreting this provision they have made the test of inconsistency a strict one. The usual statement of this test is that the special finding will overthrow the general finding only when the antagonism is apparent on the face of the record and is beyond the possibility of being removed by any evidence admissible under the issues. ${ }^{47}$ In determining this question the court will consider only the pleadings, the general verdict, and the answers to the interrogatories. ${ }^{48}$ The majority rule is that where special findings are contradictory and inconsistent with themselves they destroy each other and cannot effect the general verdict.49 This rule seems to savor more of metaphysical logic than of common sense. In cases of this type, and also in cases of the preceding type, namely, where the special findings are inconsistent with the general verdict, it is submitted that there is a practical demonstration that the jury has misunderstood the -jinstructions, has deliberately disregarded them or has made a clerical error in answering the interrogatories. Consequently the proper remedy should be to resubmit the case to the jury with appropriate instructions..$^{60}$ If this is no longer possible, judgment should be rendered on the special findings, if

${ }_{44}$ Hinze $v$. City of Iola (1914) 92 Kan. 779, 142 Pac. 947; Minor $v$. Stevens (1911) 65 Wash. 423, 118 Pac. 313, and cases cited in Ann. Cas. $1916 \mathrm{~B}, 284$, note.

45 Supra notes 15 and 16.

46 Iowa Comp. Code, 1919, sec. 7524 adds "or set aside the verdict and findings, as justice may require."

${ }^{47}$ American Car and Foundry Co. v. Vance (1912) 177 Ind. 78, 97 N. E. 327; Devine v. Federal Life Ins. Co. (1911) 250 IIl. 203, 95 N. E. 174; Osburn v. Atchison T. and S. F. R. R. (1907) 75 Kan. 746, 90 Pac. 289; Kafka v. Union Stockyards Co. (1907) 78 Neb. 140, 110 N. W. 672; Smith v. Atchison T. and S. F. R. R. (1914) 19 N. M. 247, 142 Pac. 150.

48 Drake v. Justice Gold Mining Co. (1904) 32 Colo. 259, 75 Pac. 912; Indiana Ry. v. Maurer (1903) 160 Ind. 25, 66 N. E. 156; Evansvillo and S. I. Traction Co. v. Spiegel (1911) 49 Ind. App. 412, 94 N. E. 718; Dovine v. Federal Life Ins. Co., supra note 47; Schauer v. Bodenheimer (1912) 150 Wis. 550, 137 N. W. 785.

${ }^{49}$ Drake v. Justice Gold Mining Co., supra note 48; Childress v. Lako Erie and W. R. R. (1914) 182 Ind. 251, 105 N. E. 467; Di Palma v. Woinman (1911) 16 N. M. 302, 121 Pac. 38; Donnell v. City of Greensboro (1913) 164 N. C. 330,80 S. E. 377.

50 Tatlow v. Bacon (1915) 95 Kan. 695, 149 Pac. 745; MoManus v. Thing 
they are consistent with themselves. If they are irreconcilably inconsistent with themselves, a new trial should be granted.as

The practice of submitting interrogatories is subject to two abuses. First, their form may be such as to mislead the jury, and secondly, an excessive number of questions may confuse the jury. There can be little doubt that the privilege of submitting interrogatories has been abused occasionally, ${ }^{t a}$ and that this abuse in some cases has resulted in entrapping the jury into an unintentional error. Although both under the statutes providing that the court "may" and under those providing that the court "shall" submit interrogatories, at the request of a party, trial judges have power to revise, revamp, and rearrange interrogatories and strike out repetitions and immaterial questions, naturally they have felt less hesitancy in doing so when acting under statutes of the discretionary type. Three states which have had statutes of the mandatory type have amended them so as to make them discretionary ${ }^{53}$; and two other states have amended statutes of the mandatory type by expressly limiting the number of questions." The statutes of three states require the questions to be submitted to the adverse party or his attorneys before the argument to the jury is commenced.5 Such provisions are perhaps helpful in remedying these abuses; but in the last analysis the main reliance must rest on the personal character and training of the trial judges.

Some of the advantages of submitting interrogatories are the following. (1) They provide a method of checling up the correctness of the general verdict. This is undoubtedly their chief

(1911) 208 Mass. 55, 94 N. E. 293; Loy v. Northcm Pac. $R y$. (1912) 68 Wash. 33, 122 Pac. 372.

51 IIcEwan v. New Yorle Life Ins. Co. (1914) 23 Calif. App. 694, 139 Pac. 242; Willis v. Slinner (1913) 89 Kan. 145, 130 Pac. G75; Colc v. Atchison T. and S. F. R. R. (1914) 92 Kan. 132, 139 Pac. 1177; Hcalcy New York, N. H. and H. R. R. (1897) 20 R. I. 136, 37 Atl. 676.

52 Some examples of the submission of an excessive number of interrogatories follow: one hundred and thirty-six in Atchison T. and S. F. R. R. v. Cone (1887) $37 \mathrm{Kan} .567,15 \mathrm{Pac}$ 499; one hundred and ten in Atehison T. and S. F. R. R. v. Brovin (1885) 33 Kan. 757, 7 Pac. 571; fifty-three in Harbaugh v. Cicott (1876) 33 Mich. 241; twenty in Fiol: $v$. Chicago, M. and. St. P. Ry. (1891) 83 Iowa, 253, 48 N. W. 1081.

53 California, Deering Code of Civ. Proe. 1923, sec. 625, Historical Note; Kentucky, Carroll's Codes of Practice, 1919, sec. 327, Editorial Note; Olilahoma, compare the statute quoted in Root v. Coylo (1905) 15 OHla. 574, 577, 82 Pac. 648, 649 with Comp. Sts. Ann. 1921, see. 552.

5 Kansas, Rev. Sts. 1923, ch. 60, sec. 2918. "Provided, That no one party shall in any case be entitled as a matter of right to request more than ten such special questions but the court may in its discretion allow more than ten special questions." Michigan, Comp. Laws, 1915, Eee. 12611. "Provided such special questions shall not exceed five in number and shall be each in single, short sentences readily answered by yes or no."

so Colorado, Illinois and Iowa. See supro notes 15 and 16. 
function; and the answers to them in many cases have furnished conclusive proof that the jury misunderstood the instructions, deliberately disregarded them or erred in applying them to the facts found. (2) They compel the jury to give a detailed consideration to important issues. Jurors are not accustomed to sifting issues, and are quite likely to jump at a general conclusion without methodically considering the evidence bearing on the real issues involved. Special interrogatories are especially valuable in that they compel the jury to consider the more important issues in their relation to the ultimate rights of the parties. Answers to special interrogatories may show that some errors were not prejudicial and provide a basis for curing others. It not infrequently happens that the jury will find a certain fact to have been proved which in law is an insuperable barrier to a recovery in accord with their general verdict. In such cases the error is often corrected and the ultimate rights of the parties settled at the trial without the expense and delay of a new trial. Less frequently a special finding shows that certain errors were not prejudicial. Thus a finding of a particular issue in favor of the appellant may show that an erroneous exclusion of evidence as to that issue was not prejudicial, or a finding against the appellant on a particular issue may show that an error in an instruction or in the denial of a requested instruction was harmless. (4) Interrogatories have a salutary effect on the morale of the jury. The fact that the cloak of secrecy will be lifted and the court, the parties, and the public will see its findings on particular questions of fact, will probably make the jury more conscious of its responsibility. A jury which would on general principles return a large and unwarranted verdict where a railway company was a defendant or a pretty woman was a plaintiff might well shrink from a specific finding which it felt not authorized by the evidence.

No one would claim that special interrogatories will prevent or invalidate all perverse verdicts, for obviously a verdict of dishonest or corrupt jurors who had sufficient intellectual capacity to appreciate the effects of their answers to interrogatories and to harmonize them with their general verdict, would still be unassailable. It would be much more difficult for them to do this, however, than it would be if no interrogatories were submitted; and it is believed that by requiring the jury to return findings on particular questions of fact, we may fairly expect to escape most of the verdicts which are primarily the result of sympathy, prejudice and passion. The number of chance verdicts will also be materially reduced, for interrogatories compel the jury to do more than toss a coin and keep still about it, if their verdict is to stand. The absence of special interrogatories in modern English practice is doubtless primarily due to the fact that the English 
judges still exercise their common law power of giving liberal aid to the jury in their endeavor to reach a just conclusion on matters of fact. But by constitutional provision, legislation, or judicial decision this power has been taken away from the trial judge in two-thirds of the American jurisdictions. ${ }^{c 5}$ Some check must be imposed to prevent a jury from yielding to impulse and returning a general verdict in disregard of the law or from ignoring the fair weight of the evidence. Otherwise the parties will be subjected to "a government by jury instead of a government by law." $5 \pi$

\footnotetext{
${ }^{56}$ Sunderland, op. cit. supra note 9.

s7 Emery, Government by Jury (1915) 24 YaLE LAW Jounsax, 205.
} 